\title{
PEMBERIAN MODUL DAN PELATIHAN KONSELING VOLUNTEER KOMUNITAS RUMAH BELAJAR SENEN TERHADAP PENDAMPINGAN REMAJA
}

\section{Penny Handayani ${ }^{1}$, Reneta Kristiani ${ }^{2}$, Therese Arnesthy Danupratista ${ }^{3}$, Novela Clara ${ }^{4}$, Caecilia Anggita $^{5}$, Arifa Dwiratri ${ }^{6}$, dan Nindita Naura Ramadhani ${ }^{7}$}

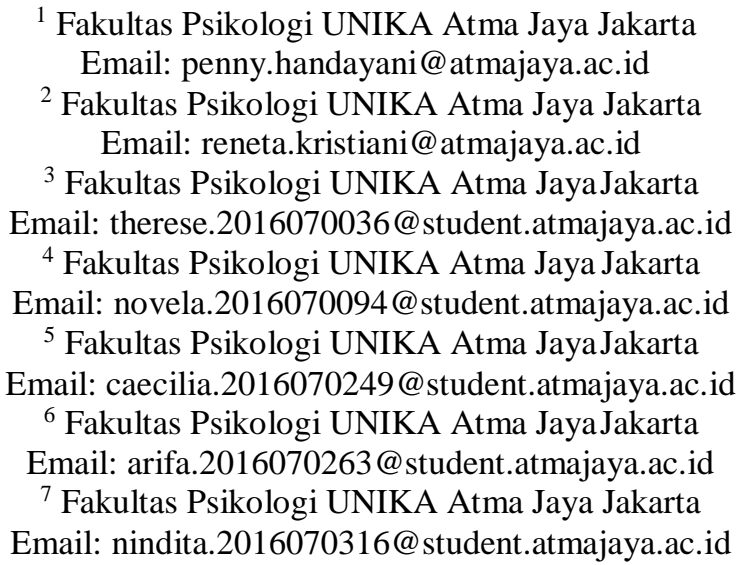

\begin{abstract}
ABSTRAK
Rumah Belajar Senen merupakan komunitas sosial yang peduli terhadap anak-anak jalanan di kawasan Senen, Jakarta Pusat. Komunitas ini menaungi anak-anak jalanan dari berbagai macam usia. Rumah Belajar Senen (RBS) berada di kawasan yang kumuh dan ditempati oleh masyarakat kaum marjinal. Anak-anak remaja yang berada di RBS memiliki lingkungan yang tidak kondusif, mereka tidak memiliki dukungan sosial yang baik mulai dari lingkup keluarga, teman, tetangga, bahkan sekolah. Tidak adanya dukungan sosial membuat anak-anak remaja RBS tidak memiliki sosok untuk bercerita, sehingga mereka sering memendam masalahnya sendiri. Dengan demikian, intervensi ini bertujuan untuk memberikan pelatihan konseling melalui modul untuk kakak pendamping di RBS agar dapat menjadi sosok yang bisa memberikan dukungan kepada remaja RBS dimulai dari sebagai tempat bercerita. Datadata yang dikumpulkan menggunakan metode observasi dan wawancara terhadap beberapa kakak pendamping dan juga beberapa remaja di RBS. Intervensi dilakukan dengan cara memberikan pelatihan cara pengaplikasian modul konseling yang sudah disusun sebelumnya. Hasil yang didapatkan dari aspek kognitif, para pendamping sudah menguasai materi. Namun untuk aspek behavior dan afeksi, para pendamping belum menguasai dengan baik. Hal ini disebabkan karena waktu yang terbatas dalam melatih kemampuan konseling sehingga behavior dan afeksi belum terlatih dengan baik.
\end{abstract}

Kata kunci: komunitas, konseling, remaja

\section{PENDAHULUAN}

Rumah Belajar Senen (RBS) merupakan komunitas sosial yang peduli terhadap anak-anak jalanan di kawasan Senen, Jakarta Pusat. Komunitas ini menaungi anak-anak jalanan dari usia empat tahun hingga enam belas tahun dan dari berbagai macam jenjang pendidikan. Menurut Kertajaya (2008), komunitas adalah sekelompok orang yang saling peduli satu sama lain dan menjalin hubungan yang erat karena memiliki interest dan value yang sama. Dalam komunitas manusia individuindividu di dalamnya dapat memiliki maksud, kepercayaan, sumber daya, preferensi, kebutuhan, risiko dan sejumlah kondisi lain yang serupa (Wenger, 2002: 4). 
Menurut Crow dan Allan (1994), komunitas terbagi menjadi dua komponen, yaitu berdasarkan lokasi dan minat. Berdasarkan lokasi berarti komunitas dilihat sebagai tempat sekumpulan orang mempunyai sesuatu yang sama secara geografis. Sedangkan, berdasarkan minat berarti komunitas didirikan karena adanya ketertarikan dan minat yang sama. Komunitas RBS sendiri memiliki kegiatan berupa memberikan pengajaran akademik untuk anak-anak di sana, namun saat ini tidak hanya aspek akademik saja yang diberikan melainkan aspek-aspek lainnya, seperti belajar mengaji, memfasilitasi minat bakat non akademik, dan sebagainya.

Anak-anak jalanan yang diasuh oleh RBS sebagian besar berkegiatan lain di luar sekolah, yakni mengamen dan melakukan arak-arakan dengan ondel-ondel. Kemudian, mereka juga memiliki latar belakang keluarga yang bisa dikatakan tidak ideal. Orangtua mereka jarang memberikan perhatian kepada anak-anaknya karena sibuk bekerja sebagai pemulung, tukang parkir, dan sebagainya. Para orangtua bahkan tidak peduli apabila anak-anaknya pergi meninggalkan rumah dan berkegiatan di luar. Dengan demikian, anak-anak RBS banyak yang tidak memiliki lingkungan keluarga yang baik dan suportif.

Selain itu, sebagian besar anak-anak RBS juga tidak memiliki lingkungan sekolah, baik guru maupun pendidik lainnya yang baik. Guru-guru di sekolah mereka banyak yang tidak peduli dengan murid-muridnya. Mereka juga tidak memberikan contoh dan bimbingan yang baik kepada siswanya. Misalnya, ketika ujian, guru-guru membantu siswanya untuk menyontek saat ujian berlangsung, kemudian para guru juga tidak mengajarkan budi pekerti yang baik kepada para siswa. Hal ini membuat siswa-siswa, termasuk anak-anak RBS, tidak memperoleh pendidikan, baik akademik maupun budi pekerti yang benar dari sekolahnya.

Selanjutnya, pergaulan yang dimiliki oleh anak-anak RBS juga tidak kondusif. Banyak dari mereka yang berteman secara bebas dengan orang-orang yang usianya jauh lebih dewasa daripada mereka seperti tukang, pemulung, dan sebagainya. Kemudian anak-anak RBS yang usianya sudah masuk masa remaja juga sering bertemu dengan teman-teman yang dikenalnya dari situs online, seperti Facebook. Mereka sering bertemu dengan orang-orang yang berbeda tanpa tahu apakah orang tersebut baik atau tidak. Para remaja RBS tidak memiliki ponsel pribadi, sehingga mereka sering ke warnet untuk bermain Facebook bersama teman- temannya. Dengan demikian, banyak remaja RBS yang memiliki pergaulan tidak sehat karena faktor lingkungan dan juga tidak adanya kontrol dari keluarga. Hal tersebut dapat terjadi karena remaja perempuan yang mengalami pematangan lebih awal mengakibatkan dirinya terlibat dalam kenakalan remaja dan ingin memiliki pasangan dan terlibat pengalaman seksual lebih cepat dibanding remaja perempuan yang mengalami pematangan saat waktunya (Baker et al.; Verhoef et al. dalam Santrock, 2015).

Berdasarkan penjelasan di atas, maka dapat terlihat bahwa lingkungan keluarga, sekolah, dan pergaulan yang dimiliki oleh anak-anak RBS sebagian besar tidak kondusif. Banyak dari ketiga aspek tersebut yang tidak bisa menopang perkembangan anak-anak RBS terutama di usia remaja ini. Perkembangan anak di masa remaja sangat dipengaruhi oleh faktor lingkungan, baik keluarga ataupun yang lain. Anak usia remaja membutuhkan perhatian dari orang-orang disekitarnya karena banyak dari aspek diri yang berkembang, terutama aspek fisik dan sosioemosionalnya.

Monks (dalam Nurhayati, 2015) membedakan masa remaja menjadi empat bagian, yaitu: masa pra-remaja atau masa pra-pubertas (10-12 tahun), masa remaja awal atau pubertas (12- 15 tahun), masa remaja pertengahan (15-18 tahun), dan masa remaja akhir (18-21 tahun). Remaja awal cenderung ingin diperhatikan dan diperhitungkan eksistensinya sebagai individu (Nurhayati, 2015). Hal ini membuat orang-orang di sekitarnya perlu memperhatikan sikap dan perilaku individu pada masa remaja awal. Selain itu, masa remaja disebut juga sebagai masa "psychological learning" dan "social learning", hal ini berarti masa remaja sedang mengalami suatu pematangan fisik dan sosial (Rifai dalam Nurhayati, 2015). 
Kemudian, adanya aspek sosioemosional yang tengah berkembang pesat di usia remaja membuat mereka membutuhkan dukungan sosial yang cukup agar bisa membentuk perilaku yang baik. Perkembangan sosioemosional pada diri sendiri digambarkan dengan penurunan self-esteem saat memasuki remaja awal karena adanya persepsi mengenai dirinya sendiri yang tidak sesuai dengan kenyataan (Santrock, 2015). Pada remaja perempuan, terlihat dari penilaian negatif yang diberikan terhadap penampilan tubuhnya. Selain itu, adanya perilaku narsisme yang mengarah pada selfcentered dan self-concerned, yaitu lebih memusatkan perhatian dan kepentingan terhadap diri sendiri dibandingkan orang lain. Pencarian identitas merupakan bentuk sosioemosional pada remaja. Remaja akan bereksperimen berbagai peran dan kepribadian untuk menemukan identitas yang cocok dengan dirinya (Erikson dalam Santrock, 2015). Apabila remaja tidak dapat menemukannya, remaja akan menarik diri dari lingkungan teman dan keluarganya. Hal ini disebut dengan identity confusion.

Kemudian, perkembangan sosioemosional dalam keluarga digambarkan dengan peran orangtua terhadap anaknya (Santrock, 2015). Orang tua perlu memonitor perkembangan anaknya yang memasuki tahap remaja dengan mengawasi kehidupan sosial, aktivitas, teman, dan akademik anak. Remaja juga perlu memberikan informasi seputar dirinya kepada orangtuanya. Keterikatan antara remaja dengan orangtua memungkinkan remaja memiliki peningkatan kompeten secara sosial.

Namun, pada kenyataannya terlihat bahwa anak remaja di RBS tidak memiliki lingkungan keluarga dan sosial yang bisa mendukung mereka. Mulai dari orangtua, guru, hingga pertemanan, tidak ada yang bisa mendukung mereka. Anak-anak remaja RBS tidak memiliki tempat untuk bercerita dan berbagi. Mereka sering menangis sendiri di kamar ketika mengalami permasalahan. Hal ini membuat mereka tidak bisa berekspresi secara bebas yang mungkin dapat menimbulkan efek ke depannya, padahal lingkungan sosial yang baik bisa membantu perkembangan sosioemosional mereka.

Dengan demikian, satu-satunya sosok yang dapat diandalkan untuk membantu perkembangan anak-anak remaja RBS adalah kakak-kakak volunteer atau pendamping yang berada di RBS. Selain dalam segi akademik, mereka diharapkan dapat membantu di segi lain, termasuk pada aspek sosioemosional, dan dapat membimbing mereka untuk menjadi pribadi yang lebih baik lagi. Kakak-kakak pendamping diharapkan bisa menjadi 'wadah' untuk anak remaja RBS bercerita, menumpahkan keluh kesah yang dimilikinya agar anak-anak remaja tersebut merasa memiliki tempat yang menjadi zona nyaman mereka.

Akan tetapi, para volunteer tidak memiliki kemampuan sebagai 'tempat bercerita' yang baik atau dalam psikologi dikenal dengan sebutan konseling, karena para volunteer memiliki latar pendidikan yang berbeda-beda seperti jurusan akuntansi, manajemen, hukum, bisnis, dan lain-lain. Selain itu, volunteer yang bergabung dalam komunitas RBS ini banyak yang sudah memiliki pekerjaan, tetapi kepedulian mereka yang tinggi untuk menolong mereka membuat peneliti ingin membantu para volunteer memiliki kemampuan konseling. Kemampuan konseling diberikan dengan cara pelatihan agar ketika para volunteer menghadapi remaja yang tengah bercerita kepada mereka, mereka dapat memberikan respon apa terhadap hal tersebut. Pelatihan adalah pembelajaran yang disediakan untuk meningkatkan kinerja pada pekerjaan saat ini (Chan, 2010). Goldstsein dan Gressner (dalam Kamil, 2010) mendefinisikan pelatihan sebagai usaha sistematis untuk menguasai keterampilan, peraturan, konsep, ataupun cara berperilaku yang berdampak pada peningkatan kinerja. Keterampilan yang dimaksud adalah keterampilan dalam melakukan konseling. Konseling adalah hubungan timbal balik antara dua orang individu, dimana yang seorang (konselor) berusaha membantu yang lain (klien) untuk mencapai pengertian tentang dirinya sendiri dalam hubungan dengan masalah-masalah yang dihadapinya. 
Konseling memiliki bermacam-macam model dalam mendekati konseli beserta masalahnya. Kata "mendekati" atau pendekatan menunjuk pada aspek pribadi konseli yang ingin disentuh dan diberdayakan oleh konselor untuk mengatasi masalahnya yang mereka hadapi (Beutler \& Harwood, 2000). Dengan demikian, intervensi ini bertujuan untuk memberikan pelatihan konseling melalui modul untuk kakak pendamping di RBS agar dapat menjadi sosok yang bisa memberikan dukungan kepada remaja RBS dimulai dari sebagai tempat bercerita. Sehingga, ketika seseorang memiliki kemampuan konseling yang baik, maka ia bisa menjadi sosok yang dibutuhkan ketika ingin bercerita dan orang-orang akan merasa nyaman ketika bercerita dengan orang yang memiliki kemampuan konseling yang baik.

Kemampuan konseling yang akan disasar oleh kelompok meliputi tiga aspek, yakni aspek kognitif, behavior, dan afeksi. Seseorang dikatakan dapat melakukan konseling dengan baik jika mereka memiliki kemampuan konseling yang meliputi ketiga aspek tersebut. Dengan demikian, intervensi ini menyasar pada aspek kualitatif dimana peneliti ingin para volunteer memiliki kemampuan konseling yang berkualitas dan selalu konsisten dengan kemampuan yang dimilikinya dengan didasarkan pada ketiga aspek tersebut yakni kognitif, behavior, dan afeksi. Peneliti lebih mementingkan kualitas dari para volunteer ketika melakukan konseling dibandingkan dengan banyaknya jumlah volunteer yang bisa melakukan konseling.

\section{METODE PELAKSANAAN/METHOD}

Metode penelitian yang digunakan peneliti adalah metode kualitatif. Dalam mengumpulkan data, peneliti melakukan Training Need Analyze (TNA) dengan menggunakan teknik wawancara kepada volunteer atau kakak pendamping Komunitas RBS yang berusia 25-30 tahun serta remajaremaja berusia 12-15 tahun yang berada di RBS. Kemudian, observasi terhadap remaja dan orangtua remaja tersebut dilakukan untuk memperkuat data yang diperoleh.

Peneliti melakukan kunjungan ke Komunitas Rumah Belajar Senen untuk mencari tahu permasalahan yang terdapat di komunitas tersebut. Komunitas Rumah Belajar Senen merupakan komunitas sosial yang berfokus untuk memberikan pendidikan dengan berbagai jenjang pendidikan.

Dalam menggali permasalah yang terdapat pada komunitas RBS peneliti menggunakan instrumen utama yaitu peneliti atau yang disebut dengan human instrument. Kemudian terdapat instrumen tambahan yang mendukung berupa panduan wawancara yang dalam penyusunannya menggunakan pertanyaan-pertanyaan yang dibutuhkan untuk melakukan intervensi serta alat untuk merekam seperti ponsel yang digunakan untuk merekam. Selain itu, peneliti melakukan kunjungan ke Komunitas RBS setiap seminggu sekali selama dua bulan untuk melakukan observasi dan juga sebagai bentuk pendekatan peneliti kepada komunitas RBS. Lalu, peneliti juga melakukan sebuah kegiatan dengan volunteer komunitas RBS untuk membuat pohon masalah untuk mengetahui akar permasalahan yang terdapat dalam komunitas RBS.

Setelah itu, mengetahui gambaran permasalahan dari komunitas RBS akhirnya peneliti menetapkan tujuan final berupa perencanaan intervensi yang akan dilakukan di komunitas RBS. Setelah penetapan tujuan, peneliti melakukan kajian literatur mengenai remaja, early adulthood, sosioemosional, konseling, dan pelatihan yang berguna sebagai pembuatan modul intervensi. Intervensi yang dilakukan oleh peneliti adalah membekali volunteer komunitas RBS dengan pelatihan konseling melalui modul konseling yang telah dirancang peneliti. Setelah diberikan pelatihan komunitas diharapkan volunteer komunitas RBS dapat menjadi sosok yang bisa memberikan dukungan kepada remaja RBS dengan cara menjadi tempat bercerita. 
Intervensi dilakukan peneliti sebanyak satu kali pertemuan dengan di Rumah Belajar Senen dengan dua sesi yang berbeda. Pada sesi pertama, dilakukan pre-test untuk mengetahui pemahaman volunteer komunitas RBS mengenai konseling sebelum dilakukannya pelatihan konseling. Selanjutnya, dilakukan pemaparan mengenai definisi konseling, tujuan, konseling, teknik konseling, prinsip konseling, karakteristik konselor, kemampuan konseling, karakteristik konseli, serta memberikan saran rujukan bila mendapatkan sebuah kasus yang tidak dapat lagi ditangani oleh volunteer komunitas RBS.

Pada sesi kedua, diisi dengan melakukan roleplay konseling oleh volunteer komunitas RBS yang bertujuan untuk melihat bagaimana pengaplikasian secara langsung berdasarkan penjelasan yang telah dipaparkan oleh peneliti. Setelah melakukan roleplay para volunteer diminta untuk sharing pengalamannya saat roleplay untuk mengetahui kendala apa yang mereka dapat saat melakukan konseling dan mendiskusikan bersama-sama hal apa yang seharusnya dilakukan jika berhadapan dengan kendala tersebut. Setelah melakukan satu rangkaian pelatihan volunteer komunitas RBS diminta mengerjakan post-test dengan soal yang sama seperti pre-test sebelumnya untuk melihat bagaimana pemahaman para volunteer terhadap materi yang diberikan oleh peneliti pada sesi pertama dan dapat dibandingkan hasilnya dengan pre-test sebelumnya apakah pelatihan yang diberikan dapat menambah pengetahuan para volunteer komunitas RBS mengenai konseling. Selanjutnya peneliti memberikan modul konseling kepada komunitas RBS agar dapat menjadi pedoman komunitas dalam melakukan konseling dan sebagai bahan pengajaran kepada generasi volunteer komunitas RBS, sehingga apa yang telah diajarkan oleh peneliti dapat berlangsung hingga seterusnya

Satu minggu setelah dilakukannya Intervensi peneliti melakukan monitoring dan evaluasi kepada volunteer komunitas RBS dengan melakukan observasi terhadap volunteer komunitas RBS saat melakukan konseling dengan anak remaja RBS untuk dapat mengetahui bagaimana kemampuan para volunteer untuk melakukan konseling. Setelah itu, peneliti melakukan sharing dengan volunteer komunitas RBS untuk mengetahui kesulitan apa yang masih dihadapi dan sebagai bentuk evaluasi peneliti kepada volunteer komunitas RBS dalam melakukan konseling.

Setelah dilakukan serangkaian kegiatan intervensi, kemampuan konseling volunteer RBS perlu dipantau agar kemampuan konseling tetap dapat dilakukan dan diberikan kepada generasi selanjutnya. Pemantauan ini dilakukan dengan cara menanyakan kepada volunteer RBS terkait konseling yang telah dilakukan dan remaja RBS mengenai proses konseling yang telah dilakukan oleh volunteer RBS.

\section{HASIL DAN DISKUSI/RESULT AND DISCUSSION}

Peneliti telah mengadakan intervensi dengan memberikan pelatihan konseling bagi volunteer RBS. Intervensi mulai dilakukan pada Sabtu, 4 Mei 2019 dan monitoring- evaluasi dilakukan pada Sabtu, 11 Mei 2019.

Tabel 1. Pelaksanaan Intervensi

\begin{tabular}{|l|l|}
\hline Tanggal & \\
\hline 4 Mei 2019 & $\begin{array}{l}\text { Intervensi (Pelatihan Konseling) } \\
\text { Pre-test. } \\
\text { Pemberian materi konseling. } \\
\text { Roleplay konseling. } \\
\text { Post-test. }\end{array}$ \\
\hline
\end{tabular}




\begin{tabular}{|l|l|}
\hline 11 Mei 2019 & $\begin{array}{l}\text { Volunteer RBS paham dengan materi konseling yang diberikan. Saat roleplay berlangsung, } \\
\text { volunteer RBS dapat mengaplikasikan konseling berdasarkan materi yang dipelajari dengan } \\
\text { cukup baik. }\end{array}$ \\
\hline 4 Mei 2019 & $\begin{array}{l}\text { Monitoring } \\
\text { Veberapa volunteer sudah dapat menerapkan konseling kepada beberapa remaja RBS. } \\
\text { terlihat bingung dan kesulitan dalam melakukan probing karena jawaban dari remaja RBS yang } \\
\text { singkat dan tidak elaboratif. }\end{array}$ \\
\hline 11 Mei 2019 & $\begin{array}{l}\text { Evaluasi 1 } \\
\text { Volunteer sangat antusias dalam mengikuti pelatihan konseling yang diberikan, hal ini terlihat } \\
\text { dari saat peneliti menjelaskan mengenai teori konseling hingga saat roleplay. Para volunteer } \\
\text { memperhatikan dengan seksama, sehingga saat diajak untuk membantu peneliti dalam } \\
\text { menjawab pertanyaan, volunteer dapat menjawabnya dengan cukup baik. Pada saat roleplay } \\
\text { para volunteer juga dapat mengaplikasikan teori tersebut dengan baik. }\end{array}$ \\
\hline $\begin{array}{l}\text { Evaluasi } 2 \\
\text { Setelah volunteer menerapkan konseling kepada beberapa remaja RBS, peneliti menanyakan } \\
\text { perasaan dan kesulitan apa saja yang dirasakan oleh volunteer. Volunteer merasa puas terhadap } \\
\text { materi konseling yang didapatkan dan mengatakan konseling tidak semudah yang dipikirkan } \\
\text { karena jawaban dari remaja RBS yang singkat dan tidak elaboratif. Namun, hal tersebut tidak } \\
\text { membuat para volunteer untuk terus mencoba dan berlatih agar dapat membantu para remaja } \\
\text { RBS mempunyai tempat cerita yang nyaman. }\end{array}$ \\
\hline
\end{tabular}

\section{Hasil intervensi}

Setelah melakukan intervensi selama satu hari penuh dan dilakukannya monitoring- evaluasi atas intervensi yang sudah dilakukan, kendala yang dihadapi hanyalah keterbatasan waktu karena banyaknya kegiatan dari pihak komunitas dalam mempersiapkan acara RBS Got Talent. Melalui intervensi dan monitoring-evaluasi didapatkan hasil bahwa dari ketiga aspek yang peneliti sasar, yakni aspek kognitif, afeksi, dan behavior, yang mencapai target atau dinyatakan tercapai adalah aspek kognitif. Aspek kognitif menandakan bahwa para pendamping RBS sudah mampu menguasai materi dengan baik.

\section{Aspek kognitif}

Aspek kognitif diukur dengan cara memberikan post-test dan pre-test kepada kakak pendamping RBS. Pre-test diberikan sebelum pemberian materi mengenai konseling dilakukan dan post-test diberikan setelah rangkaian pelatihan selesai. Berikut adalah hasil dari pre-test dan post-test dari para volunteer:

Tabel 2. Hasil Pre-test dan Post-test

\begin{tabular}{|c|l|c|c|c|}
\hline NO & \multicolumn{1}{|c|}{ NAMA } & PRE-TEST & POST-TEST & $\begin{array}{c}\text { DERAJAT } \\
\text { KEBERHASILAN }\end{array}$ \\
\hline 1 & Samuel & 6,5 & 9 & 0,225 \\
\hline 2 & Era & 4 & 8 & 0,36 \\
\hline 3 & Eva & 3 & 8,5 & 0,495 \\
\hline 4 & Irene & 7 & 7 & 0 \\
\hline 5 & Komang & 6 & 8 & 0,36 \\
\hline 6 & Yolla & 4,5 & 8 & 0,315 \\
\hline
\end{tabular}




\begin{tabular}{|c|l|c|c|c|}
\hline 7 & Adinda & 5,5 & 4,5 & $-0,09$ \\
\hline 8 & Ai & 4,5 & 8 & 0,315 \\
\hline 9 & Egga & 2,5 & 9 & 0,585 \\
\hline
\end{tabular}

Gambar 1. Grafik Hasil Pre-test dan Post-test

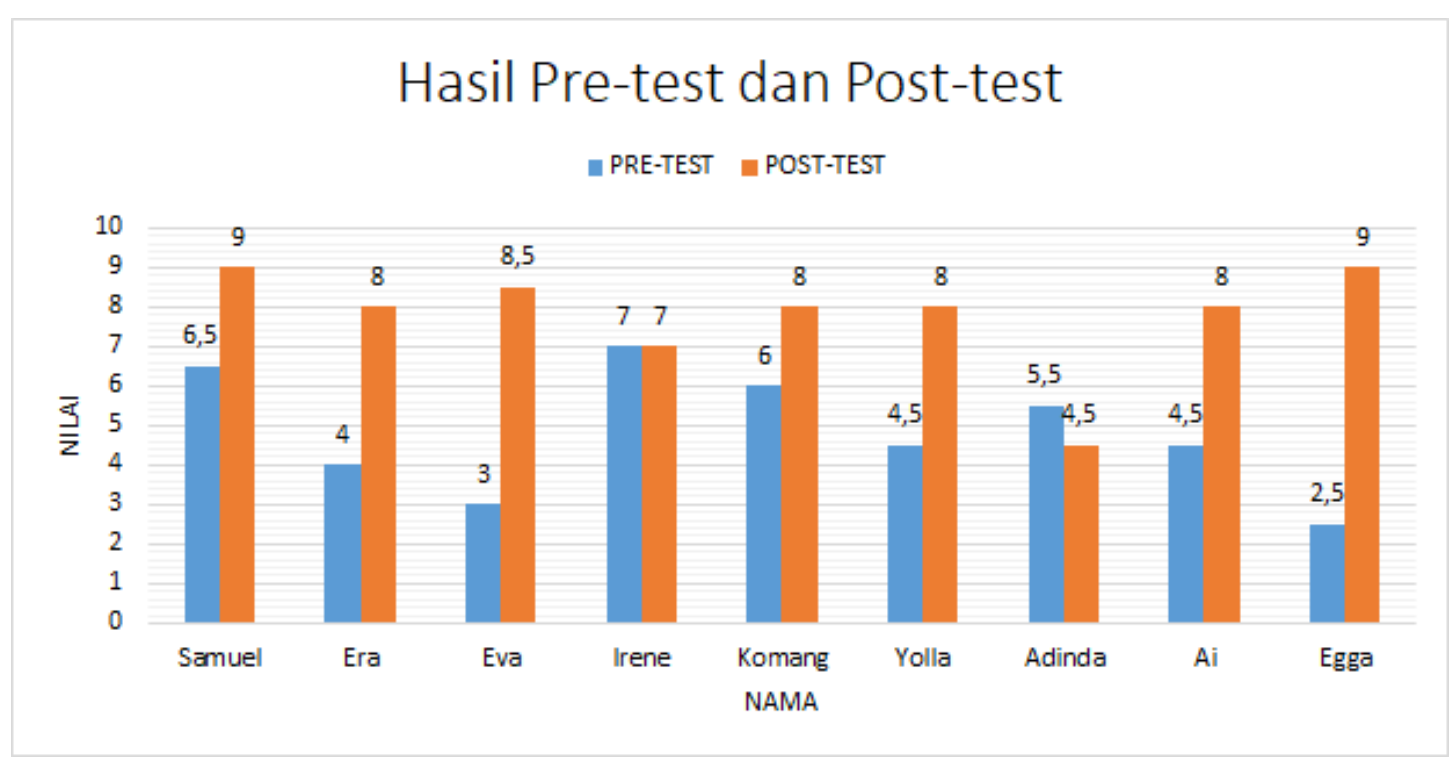

Hasil yang didapat dari pre-test dan post-test ini adalah volunteer RBS sudah mengerti materi konseling yang disampaikan. Hal ini terlihat bahwa adanya peningkatan pada nilai post- test oleh 7 dari 9 volunteer RBS. Hasil ini menunjukan bahwa para relawan sudah memahami materi yang diberikan karena nilai skor sebagian besar relawan meningkat dari sebelum diberikan materi sampai setelah diberikan materi. Terlihat pula ketika para volunteer secara langsung mengaplikasikan konseling, volunteer dapat menanggapi cerita klien dengan cukup baik dengan teknik-teknik yang telah diajarkan peneliti.

\section{Aspek behavior}

Aspek behavior diukur dengan cara mengobservasi frekuensi perilaku yang sudah diajarkan sebelumnya di sebuah tabel perhitungan (behavior checklist) dan kemudian dihitung berapa banyak frekuensi yang muncul selama proses konseling berlangsung. Perilaku yang dihitung frekuensinya adalah teknik verbal dalam konseling yakni probing, parafrase, normalisasi, reframing, dan konfrontasi. Kemudian teknik non-verbal seperti respon minimal dan gestur tubuh. Berdasarkan hasil monitoring evaluasi, para pendamping RBS belum menunjukkan peningkatan yang signifikan dalam melakukan teknik verbal konseling ketika role play dan pada saat praktek langsung. Jumlah frekuensi yang meningkat hanya rata-rata sebanyak dua atau tiga perilaku dari role play sebelumnya untuk teknik komunikasi verbal. Akan tetapi, terdapat peningkatan yang cukup signifikan untuk teknik komunikasi non-verbal dari ketika role play dan pada saat praktek langsung. Berdasarkan observasi, frekuensi komunikasi non-verbal seperti gestur tubuh yang terbuka, anggukan kepala, eye contact, dan respon minimal sudah terlihat dari kakak pendamping RBS ketika melakukan praktek konseling langsung. 
Ketidaktercapaian aspek behavior dikarenakan waktu untuk berlatih yang terbatas karena RBS juga memiliki kegiatan lain sehingga waktu untuk berlatih melakukan teknik-teknik konseling sangat terbatas. Selain itu, latar belakang pendidikan juga berpengaruh terhadap ketanggapan kakak pendamping terhadap materi yang disampaikan. Seperti misalnya untuk kakak pendamping dengan latar belakang pendidikan guru, mereka lebih bisa mengaplikasikan teknik konseling dengan lebih lancar dibandingkan dengan kakak pendamping yang berlatar belakang ekonomi dan bisnis karena kakak pendamping berlatar belakang tersebut lebih kaku ketika mempraktekan teknik konseling secara langsung.

Selain latar belakang pendidikan, gender juga berpengaruh terhadap kelancaran kakak pendamping selama proses konseling berlangsung. Kakak pendamping perempuan cenderung lebih santai dan lancar dalam mengaplikasikan teknik-teknik konseling baik saat role play maupun ketika praktek langsung. Berbeda dengan kakak pendamping laki-laki yang cenderung lebih kaku dan banyak berfikir ketika saat role play serta praktek langsung.

\section{Aspek afeksi}

Aspek afeksi diukur dengan cara memberikan pertanyaan mengenai perasaan yang volunteer rasakan selama mengikuti roleplay, hasilnya volunteer merasa senang karena mereka tidak hanya belajar melalui teori yang dijelaskan saja tetapi juga dapat secara langsung mempraktekan teori yang telah diberikan tersebut dengan cara menjadi konselor untuk sesama volunteer lainnya.

Selain itu peneliti juga memberikan pertanyaan mengenai perasaan yang dirasakan oleh volunteer atas pelatihan mengenai konseling yang telah diberikan oleh peneliti kepada volunteer. Volunteer merasa bahwa mereka sangat senang dan terbantu akan kedatangan peneliti untuk memberikan pelatihan mengenai konseling, mereka sangat berterima kasih kepada peneliti karena telah memberikan pelatihan tersebut yang sebelumnya sangat jarang dilakukan oleh pihak luar. Hasil dari pelatihan ini dapat mereka gunakan untuk membantu anak-anak Rumah Belajar Senen.

Kemudian saat sesi sharing dan evaluasi, volunteer mengungkapkan perasaannya bahwa ketika klien menceritakan kisah sedihnya, volunteer yang berperan sebagai konselor juga turut merasakan kesedihannya karena melihat klien juga menunjukan raut wajah yang bercerita saat bercerita. Selain itu, terdapat beberapa orang yang mengatakan bahwa ketika melakukan konseling mereka memahami bahwa value yang dimiliki masing-masing orang berbeda sehingga ketika mendengarkan cerita dari klien, volunteer mencoba untuk mengerti dan menerima yang dikatakan oleh klien walaupun hal tersebut bertentangan dengan dirinya.

\section{SIMPULAN DAN SARAN}

Berdasarkan hasil intervensi yang telah dilakukan, maka dapat disimpulkan bahwa aspek yang mampu dicapai dari ketiga aspek yang disasar yakni kognitif, afeksi, dan behavior, hanya aspek kognitif saja yang mencapai target dari tujuan intervensi. Hal ini disebabkan karena waktu yang terbatas untuk melatih kemampuan mempraktekkan teknik-teknik konseling. Keterbatasan waktu membuat para pendamping tidak bisa melatih kemampuan konselingnya sehingga skill tersebut belum terasah dengan baik.

Kemudian faktor latar belakang pendidikan dan gender juga berpengaruh terhadap kecakapan kakak pendamping ketika mempraktekkan konseling. Kakak pendamping dengan latar belakang guru cenderung lebih lancar ketika berpraktek langsung dibanding dengan kakak pendamping berlatar belakang yang lain. Sedangkan untuk gender, kakak pendamping 
perempuan cenderung lebih lancar ketika mengaplikasikan teknik-teknik konseling dibandingkan dengan kakak pendamping laki-laki yang cenderung lebih kaku.

Lalu saran yang dapat diberikan adalah diharapkan kakak pendamping dapat terus melatih kemampuan konselingnya agar dapat digunakan untuk kedepannya kelak. Kemudian, kakak pendamping yang telah mendapatkan pelatihan konseling diharapkan dapat mengajarkan ilmunya ke kakak pendamping lainnya agar semua kakak pendamping yang berada di RBS memiliki kemampuan konseling yang baik, serta dapat diturunkan ke generasi-generasi penerus mendatang. Selain itu, sifat volunteer (kakak pendamping) yang tidak menetap di RBS dapat menyebabkan kegiatan konseling dengan satu kakak pendamping yang tidak menetap juga. Oleh karena itu, diperlukan rekam jejak konseling yang telah dilakukan oleh kakak pendamping sebelumnya perlu ditulis dan dapat diajukan kepada kakak pendamping berikutnya untuk konseling lanjutan.

Kemudian, saran yang dapat diberikan untuk mengontrol volunteer dalam memberikan konseling selain melalui rekam jejak adalah dengan bergabungnya salah satu peneliti sebagai volunteer di RBS sehingga proses kegiatan konseling dapat dipantau dan dikontrol oleh salah satu peneliti yang bergabung dengan RBS tersebut.

\section{UCAPAN TERIMA KASIH/ACKNOWLEDGEMENT}

Peneliti mengucapkan terima kasih yang sebesar-besarnya atas bantuan Bapak/Ibu yang telah bersedia mendukung peneliti dalam mewujudkan tercapainya pelatihan konseling yang dapat berjalan dengan baik. Dukungan diberikan dalam bentuk pemberian informasi berupa data- data dan waktu luang yang diberikan untuk melaksanakan pelatihan konseling ini oleh volunteer Rumah Belajar Senen (RBS) dalam pemenuhan tugas akhir mata kuliah pendidikan berbasis komunitas. Serta kepada anak remaja Rumah Belajar Senen yang telah mau menerima peneliti untuk bisa lebih dekat dengan mereka dan mau meluangkan waktu dengan peneliti melakukan sharing dan bermain bersama.

\section{REFERENSI}

Beutler, L. E., \& Harwood, T. M. (2000). Prescriptive psychotherapy: A practical guide to systematic treatment selection. New York, NY, US: Oxford University Press.

Chan, J. F. (2010). Training fundamentals: Pfeiffer essential guides to training basics.

San Francisco, CA: John Wiley and Sons, Inc.

Crow, G., \& Allan, G. (1994). Community life: An introduction to local social relations [e-book]. Diakses pada 1 April 2019 pada https://books.google.co.id.

Kamil, M. (2012). Model pendidikan dan pelatihan: Konsep dan aplikasi. Bandung: Alfabeta.

Kertajaya, H. (2008). Arti komunitas. Bandung: Gramedia Pustaka. 
Nurhayati, T. (2015). Perkembangan perilaku psikososial pada masa pubertas. Jurnal Pendidikan Sosial dan Ekonomi, 4(1). Diakses pada 1 April 2019 dari http://www.syekhnurjati.ac.id/jurnal/index.php/edueksos/article/view/649.

Santrock, J. W. (2015). Life-span development (15 ${ }^{\text {th }}$ ed.). New York, USA: McGrawHill Education.

Wenger, E., McDermott. R., \& Snyder, W. M. (2002). A guide to managing knowledge:

Cultivating communities of practice. Boston, USA: Harvard Business School Press 